\title{
Cercospora leaf spot of sugar beet (Cercospora beticola Sacc.) Part I. Biology and occurrence
}

\section{Chwościk buraka cukrowego (Cercospora beticola Sacc.) Część I. Biologia i występowanie}

\author{
Jacek Piszczek ${ }^{1 *}$, Ewa Moliszewska², Adam Sitarski
}

\section{Summary}

Cercospora beticola Sacc. is the most destructive foliar pathogen of sugar beet leaves in many beet growing regions on the world. This paper summarized the most important knowledge about the systematic position, biology and morphology of the pathogen and its hosts. Conditions favoring infection of host plants and the influence of weather conditions on disease development have been described as well. Basic information regarding spread and overwintering of $C$. beticola under natural conditions is provided. In addition an effects of $C$. beticola infection on host plants and losses in root and sugar yield resulting from this disease have been described. The presented discussion was based on Polish and worldwide literature.

Key words: Cercospora beticola, biology, morphology and taxonomy of fungus, infection weather condition, disease harmfulness

\section{Streszczenie}

Cercospora beticola Sacc. jest najgroźniejszym patogenem liści buraka cukrowego we wszystkich rejonach uprawy tej rośliny. W niniejszym opracowaniu zebrano najważniejszą wiedzę dotyczącą pozycji systematycznej, biologii, morfologii grzyba oraz jego żywicieli. Opisano warunki, w których dochodzi do infekcji roślin gospodarza oraz wpływ warunków atmosferycznych na rozwój choroby na roślinach. Podano podstawowe informacje na temat rozprzestrzeniania się oraz zimowania C. beticola w warunkach naturalnych. Opisano wpływ na rośliny gospodarza oraz powodowane straty w plonie korzeni i cukru. Całość zagadnienia omówiono w oparciu o polską i światową szeroką bazę literaturową.

Słowa kluczowe: Cercospora beticola, biologia, morfologia i taksonomia grzyba, warunki pogodowe infekcji, szkodliwość choroby

\footnotetext{
${ }^{1}$ Instytut Ochrony Roślin - Państwowy Instytut Badawczy

Terenowa Stacja Doświadczalna w Toruniu

Pigwowa 16, 87-100 Toruń

${ }^{2}$ Uniwersytet Opolski, Wydział Przyrodniczo-Techniczny, Instytut Biotechnologii

Kardynała Kominka 6a, 45-032 Opole

${ }^{3}$ Kutnowska Hodowla Buraka Cukrowego Sp. z o.o.

Straszków 12, 62-650 Kłodawa

*corresponding author: j.piszczek@iorpib.poznan.pl
} 


\section{Wstęp / Introduction}

Pierwsze doniesienia o chwościku jako chorobie buraka cukrowego oraz innych buraków uprawnych i gatunków dzikich rodzaju Beta pojawiły się pod koniec XIX wieku (Saccardo 1878). Choroba najprawdopodobniej wywodzi się z terenów Europy Środkowej i obszaru śródziemnomorskiego (Groenewald i wsp. 2005). Zgodnie z Saccardo (1886), w XIX wieku rozprzestrzenienie Cercospora beticola obejmowało Włochy, Francję, Austrię, Niemcy, Portugalię, Amerykę Północną i Południową. Już w 1886 roku chwościk buraka został określony jako jedna z najgroźniejszych chorób buraka cukrowego w Niemczech (von Thümen 1886). Jednocześnie von Thümen (1886) jako jeden $z$ pierwszych dokładnie opisał rozprzestrzenianie się, patogeniczność oraz objawy chorobowe powodowane przez grzyba $C$. beticola .

Na początku XX wieku Pool i McKay (1916a) przeprowadzili pierwsze doświadczenia w celu określenia warunków klimatycznych sprzyjających infekcji przez $C$. beticola. Określili także przeżywalność patogena, źródła zakażenia, patogenezę oraz zidentyfikowali inne gatunki buraka i chwasty jako gospodarzy chwościka (McKay i Pool 1918). Wykazali, że C. beticola jest przenoszony lokalnie przez wiatr, owady i wodę używaną do nawadniania. Określili również wpływ choroby na plon korzeni i zawartość cukru. W późniejszych latach określono okres przeżywalności grzybni $C$. beticola w piasku i glebie (Nagel 1938), wpływ C. beticola na gnicie korzeni (Smith i Ruppel 1971) oraz oznaczono toksyny wytwarzane przez grzyba (Daub 1982; Milat i wsp. 1992).

\section{Taksonomia, morfologia i żywiciele I Taxonomy, morphology and hosts}

Cercospora beticola Sacc. to przedstawiciel mitosporowych grzybów z rodzaju Cercospora. W przeszłości opisywany też był pod nazwami Cercospora beticola var. beticola, Cercospora beticola var. poonensis i Cercosporina beticola (Index Fungorum 2018). Według „Ainsworth \& Bisby's dictionary of the fungi" rodzaj ten jest obecnie zaliczany do grupy grzybów anamorficznych, a od 1991 roku jego oficjalnie akceptowana nazwa to Pseudocercospora (Kirk i wsp. 2008), choć nazwa ta zupełnie nie przyjęła się w praktyce w odniesieniu do wielu gatunków, w tym dla C. beticola. Rodzaj ten do niedawna był przedstawicielem klasy Hyphomycetes, rzędu Hyphomycetales. Wśród Hyphomycetes rodzaj Cercospora stanowił jeden z najliczniejszych rodzajów (Corlett 1991; Goodwin i wsp. 2001). Gatunki z rodzaju Cercospora są bardzo rozpowszechnione i porażają rośliny z wielu rodzin (Groenewald i wsp. 2006).
Szczegółowo rozpoznano 659 gatunków należących do tego rodzaju (Crous i Groenewald 2005), choć obecnie Index Fungorum podaje aż 3178 rekordów dla nazwy Cercospora (Index Fungorum 2018). Dwa z nich, C. beticola i C. apii są morfologicznie identyczne i oba porażają buraka oraz seler (Groenewald i wsp. 2005, 2006). Jednak C. apii jest głównie izolowany z selera, a $C$. beticola $\mathrm{z}$ buraka (Groenewald i wsp. 2006). Cercospora beticola może porażać także szereg pospolitych chwastów, takich jak komosa biała (Chenopodium album L.), szarłat szorstki (Amaranthus retroflexus L.), babka zwyczajna (Plantago major L.), ślaz okrągłolistny (Malva rotundifolia L.), łopian większy (Arctium lappa L.), powój polny (Convolvulus arvensis L.), rdest powojowaty (Polygonum convolvulus L.) (Lartey i wsp. 2003; Groenewald i wsp. 2005) oraz krokosz barwierski (Carthamus tinctorius L.) (Lartey i wsp. 2003, 2007).

Cercospora beticola charakteryzuje się tworzeniem długich, igłowatych, hialinowych konidiów, które w zależności od warunków środowiskowych mają kilka mikrometrów szerokości oraz posiadają od kilku do 14 ścian poprzecznych, a ich długość dochodzi do $100 \mu \mathrm{m}$ w hodowli na pożywkach (Ruppel 1986; Jacobsen i Franc 2009). W warunkach ciepłej i wilgotnej pogody liczba komórek w konidiach jest większa (Pool i McKay 1916a; Khan i wsp. 2009). Stadium płciowe grzyba jest nieznane, tym niemniej Groenewald i wsp. (2008) oraz Bolton i wsp. (2012) wskazują na pośrednie dowody rozmnażania płciowego $C$. beticola. Wskazuje na to także fakt zrównoważonego występowania dwóch grup kojarzeniowych MATT 1-1 i MATT 1-2 w różnych, nawet małych populacjach grzyba. Podobną sytuację w populacji polskich izolatów opisał Piszczek (2010). U C. beticola, w aspekcie jego rozmnażania płciowego postuluje się heterotaliczność, a jego cykl określono jako kryptoseksualny (Groenewald i wsp. 2006, 2008). Jednocześnie inni autorzy podkreślają, że askospory prawdopodobnie mogą być źródłem zróżnicowania genetycznego u tego gatunku, choć raczej w ograniczonych populacjach (Vaghefi i wsp. 2017). Możliwość występowania płciowych form grzyba na innych roślinach żywicielskich sugerują Bolton i wsp. (2012). Łatwo uzyskiwana w warunkach polowych zmienność genetyczna odzwierciedlona w odpornościach względem fungicydów sugeruje istotną rolę rozmnażania płciowego u tego gatunku. Płciowe stadia rozwojowe rodzaju Cercospora zaliczane są do rodzaju Mycosphaerella w typie Ascomycota (Workowce) (Kirk i wsp. 2008).

Moretti i wsp. (2004) wykazali dużą zmienność fenotypową grzyba występującą na poziomie populacji zasiedlającej pojedynczy liść. Grzyb rozwijający się na pożywkach agarowych przybiera kolor od jasnoszarego, poprzez oliwkowy do ciemnego, przy czym izolaty ciemne uważane są za bardziej patogeniczne (Hetzer i Kiss 1964; Ruppel 1972a; Moretti i wsp. 2004). 


\section{Występowanie, warunki rozwoju i infekcji, rozprzestrzenianie i zimowanie grzyba I Occurrence, development and infection conditions, spreading and wintering of fungus}

Cercospora beticola występuje w klimacie umiarkowanym i ciepłym, wszędzie tam gdzie uprawiane są buraki (Holtschulte 2000). W zależności od przyjętej strategii analiz materiału genetycznego otrzymywane są różne dane, co do genetycznego zróżnicowania światowej populacji patogena. Najnowsza analiza wykonana przez Vaghefi i wsp. (2017) metodą GBS (genotyping-by-sequencing) z użyciem techniki SNP (single nucleotide polymorphisms) dla izolatów rodzaju Cercospora otrzymanych z Beta vulgaris (burak cukrowy, burak ćwikłowy i boćwina) i pochodzących z USA oraz Europy wskazuje na pewien poziom zróżnicowania tej populacji. Wśród otrzymanych kultur występował głównie $C$. beticola, co pozostaje w zgodzie z dotychczasową wiedzą, iż jest to główny sprawca symptomów chwościka buraka. Jednakże obok niego, na dwóch stanowiskach uprawy buraka z regionu Nowego Jorku, wykryto także Cercospora cf. flagellaris, który stanowił 3\% uzyskanej populacji. Wyniki analizy sekwencji mikrosatelitarnych i SNP pozwoliły na wyróżnienie w tej populacji trzech klastrów, składających się z 60, 120 i 127 izolatów. Klaster 1 obejmował głównie szczepy hawajskie, choć 5 szczepów z Hawajów lokowało się w klastrze 3, a 9 kolejnych w klastrze 2, który to obejmował głównie izolaty pochodzące z Nowego Jorku, Michigan i 2 izolaty z Dakoty Północnej oraz izolaty niemieckie. Klaster 3 był bardzo zróżnicowany, co do pochodzenia izolatów w nim zgrupowanych i obejmował szczepy z Europy, Hawajów, Nowego Jorku i Dakoty Północnej. Badania te potwierdziły wcześniejsze doniesienia o światowym rozprzestrzenianiu się genotypów C. beticola. W doświadczeniu tym, w jednej z lokalizacji znaleziono linie $C$. beticola o cechach wspólnych dla szczepów europejskich i pochodzących z regionu Nowego Jorku. Jak sugerują autorzy, potencjalną drogą migracji patogena na duże odległości mogą być zakażone nasiona, głównie chodzi o surowy materiał nasienny buraka cukrowego (kłębki), choć z drugiej strony, jak wskazują badania, raczej nie notuje się tego patogena na nasionach buraka. Wobec tego, pewnym wyjaśnieniem może być fakt, że dostępne w handlu nasiona buraka ćwikłowego nie są ocierane/polerowane, tak jak w przypadku buraka cukrowego, w celu usunięcia zewnętrznej warstwy korkowej (potencjalnego siedliska patogena). Choć i to źródło jest kwestionowane, gdyż analizy bezpośrednie materiału nasiennego w firmach amerykańskich będących dawcami materiału do badań, nie wykazały skażenia nasion przez $C$. beticola, ponadto występowanie $C$. beticola w uprawach nasiennych jest rzadkie. Wobec powyższego, rozprzestrzeniane się genotypów $C$. beticola na duże odległości ze skażonym materiałem siewnym wydaje się wątpliwe, nie można także przypisywać udziału w tym procederze askosporom. Dlatego należy zwracać uwagę na możliwy transfer genotypów z udziałem alternatywnych żywicieli, takich jak chwasty, porażone resztki roślinne lub inokulum przenoszone wraz z glebą. Innym wiarygodnym sposobem międzykontynentalnej transmisji $C$. beticola jest handel zakażonymi, alternatywnymi roślinami żywicielskimi, do których zaliczyć można np. chryzantemy (handel kwiatami ciętymi i całymi roślinami). Jak podają Groenewald i wsp. (2013), C. beticola zidentyfikowano na takich właśnie roślinach (Vaghefi i wsp. 2017).

Optymalnymi warunkami dla rozwoju grzyba i infekcji jest temperatura powietrza od 25 do $30^{\circ} \mathrm{C}$ oraz 5 do 8 godzin wilgotności względnej powyżej 90\% lub obecność wody na liściach (Pool i McKay 1916b; Wallin i Loonan 1972; Wolf i wsp. 2001). Aktywność życiowa grzyba maleje w temperaturze poniżej $15^{\circ} \mathrm{C}$, a przy temperaturze $10^{\circ} \mathrm{C}$ sporulacja i infekcja nie występują (Jacobsen i Franc 2009). Infekcja nasila się podczas okresów suchych, występujących w dzień i wilgotnych w nocy. Odwrócenie tej zależności na wilgotne okresy w dzień i suche w nocy powoduje jej spowolnienie. Wydzielanie wody przez aparaty szparkowe powoduje hydrotropizm strzępki infekcyjnej, co prowadzi do silnej penetracji tkanek liścia. Konidia mogą przetrwać kilka cykli sucho/mokro (Rathaiah 1977). Gęstość tkanki liścia nie wpływa przy tym na zdolności infekcyjne patogena (Ruppel 1972b). Nie znaleziono także zależności pomiędzy odpornością gospodarza a gęstością stromy (Solel i Minz 1971; Ruppel 1972b).

Okres pomiędzy infekcją a wystąpieniem pierwszych objawów na liściach jest zróżnicowany. Według Rathaiah (1977) oraz Steinkamp i wsp. (1979) są one widoczne po pięciu dniach od zakażenia, a konidia po infekcji pierwotnej produkowane są po 7-21 dniach, w zależności od warunków pogodowych i stanu rośliny. Pierwsze zmiany na liściach są możliwe do dostrzeżenia przy pomocy lupy po 5-6 dniach i mają postać chlorotycznych zagłębień w powierzchni liścia (Steinkamp i wsp. 1979). Plamki powiększają się do około $1 \mathrm{~mm}$ średnicy i po 10-13 dniach od momentu infekcji pojawia się wokół nich charakterystyczna, czerwonobrunatna obwódka (Pool i McKay 1916b; Steinkamp i wsp. 1979). Po uformowaniu się nekrotycznych plamek, konidia pojawiają się po około trzech dniach (Rossi 2000), przy czym na roślinach podatnych (buraki ćwikłowe) mogą się pojawiać przy wysokiej wilgotności już po 24 godzinach (Meredith 1967). Zarodnikowanie nasila się przy wilgotności powietrza powyżej $87 \%$, a zarodniki są odrywane i przenoszone przez wiatr (Khan i wsp. 2008, 2009). Największe stężenie konidiów w powietrzu zanotowano podczas nasilającego się wiatru i podnoszącej się temperatury w połączeniu ze spadającą wilgotnością powietrza (Lawrence i Meredith 1970). Także opady i nawadnianie z góry prowadzą do odrywania się i rozprzestrzeniania konidiów (Meredith 1967). Grzyb rozprzestrzenia się głównie na krótkie dystanse, $\mathrm{z}$ rośliny na roślinę. Choroba rozwija się najpierw na pierwotnie zaka- 
żonych roślinach, a dopiero potem przenosi się na kolejne (Vereijssen i wsp. 2006, 2007).

Grzybnia zimuje na resztkach liści i na innych roślinach żywicielskich. W takim przypadku może przetrwać w glebie lub na jej powierzchni od 10 do 22 miesięcy (Vereijssen i wsp. 2005; Khan i wsp. 2008). Poza tkanką żywiciela niewielki procent konidiów może przetrwać przy umiarkowanej temperaturze i niskiej wilgotności względnej nawet 8 miesięcy (Khan i wsp. 2008). W powietrzu pierwsze zarodniki konidialne pojawiają się na długo przed wystąpieniem pierwszych objawów choroby. Według Tedforda i wsp. (2018) nawet na 2-3 miesiące przed tym momentem, ale ich obecność w powietrzu nie jest czynnikiem decydującym o wystąpieniu choroby na plantacji. Niektórzy autorzy wskazują na możliwości infekcji roślin buraka cukrowego poprzez korzenie oraz przemieszczanie systemiczne do liści (Vereijssen i Schneider 2003; Vereijssen i wsp. 2004). Tej drogi zakażenia nie potwierdzają badania Khana i wsp. (2008). Źródłem zakażenia mogą być także nasiona (Lartey i wsp. 2005).

\section{Działanie chorobotwórcze i powodowane straty I Pathogenic effect and losses caused}

Chwościk buraka jest jedną z najbardziej rozpowszechnionych chorób tej rośliny i powodującą największe straty liści buraka cukrowego (Weiland i Koch 2004). Wysoką szkodliwość $C$. beticola potwierdza wielu autorów (Kerr i Weiss 1990; Holtschulte 2000). Straty powodowane są dwustopniowo: po pierwsze niszczona jest powierzchnia asymilująca liści rośliny, kolejne straty wynikają z odbudowy aparatu liściowego przez roślinę (Rossi i wsp. 2000). Crane i Calpouzos (1969) stwierdzili, że średnia ilość wytwarzanych liści na podatnej roślinie buraka cukrowego w przypadku braku ochrony chemicznej wzrasta z 51 do 61. Występowanie chwościka w dużej mierze uzależnione jest od obecności źródła inokulum (Rees i wsp. 2007) oraz warunków pogodowych (Weiland i Koch 2004). Straty wynikają z niższej zawartości cukru w korzeniach, niższego plonu korzeni oraz podwyższenia zawartości sodu, potasu i azotu- $\alpha$-aminowego, co w sumie prowadzi do spadku plonu cukru technologicznego (Coe 1967; Rossi i wsp. 2000). Przy dobrych warunkach dla rozwoju grzyba, straty mogą sięgnąć nawet 55\% plonu cukru (Shane i Teng 1992; Rossi i wsp. 2000).

Do początku lat 80 ., kiedy uprawiano w Polsce odmiany wielokiełkowe, w zasadzie nie notowano większych problemów z chwościkiem buraka. Posiadały one odporność wyniesioną z odmiany CLR (odpornej na chwościka) wyhodowanej przez firmę Buszczyński, a pochodziła ona z materiałów włoskich (Podlaski 2006). Wzrastające zagrożenie chwościkiem buraka w Polsce datowane jest od lat 90. XX wieku, kiedy wprowadzono na rynek nieodporne na
C. beticola odmiany jednokiełkowe (Nowakowska i wsp. 1997). Podobne obserwacje pochodzą także ze Stanów Zjednoczonych (Windels i wsp. 1998). Nie bez znaczenia jest tu także zmiana sposobu zbioru korzeni, polegająca na pozostawieniu w glebie główek i liści buraków, będących w kolejnych latach źródłem zakażenia (Schäufele i Wevers 1996). W warunkach polskich chwościk pojawia się zwykle w drugiej połowie lipca lub pierwszej połowie sierpnia (Piszczek 2010), choć w ostatnich latach obserwowana jest tendencja do wcześniejszego występowania choroby. Jako pierwsze atakowane są liście starsze, później choroba rozprzestrzenia się na liście młodsze. Nekrotyczne plamki są okrągłe, z popielatoszarymi środkami, otoczonymi obwódkami o kolorze od ciemnobrązowego do czerwonopurpurowego (Steinkamp i wsp. 1979). Cercospora beticola może atakować liście, liścienie oraz ogonki liściowe buraka cukrowego (Nagel 1938). Z czasem plamki zlewają się, prowadząc do całkowitego zasychania liści. Całkowite zniszczenie liści stymuluje roślinę do odbudowy rozety liściowej, co z kolei pociąga za sobą straty cukru w korzeniach oraz prowadzi do powstawania długiej, stożkowatej główki korzeniowej (Adams i Schäufele 1996; Rossi i wsp. 2000).

Cercospora beticola produkuje dwa rodzaje toksyn: cerkosporynę i betakoliny, które uczestniczą w procesie infekcji i są odpowiedzialne za powstawanie nekroz na liściach (Goodwin i Dunkle 2010). Cerkosporyna jest toksyną uniwersalną dla rodzaju Cercospora i produkowana jest podczas wegetatywnego wzrostu grzyba w warunkach nasłonecznienia (Kuyama i Tamura 1957; Balis i Payne 1971; Daub 1982). Jej biosynteza przebiega tylko w obecności światła i jest uzależniona od warunków środowiska, takich jak dostępność składników pokarmowych, pH, źródło węgla oraz azotu, a także wzajemny stosunek tych dwóch pierwiastków, i jest hamowana przez temperatury powyżej $30^{\circ} \mathrm{C}$. Stwierdzono, że cerkosporyna wytwarzana jest w fazie wegetatywnej, a warunki pokarmowe stymulujące pojawianie się konidów jednocześnie hamują produkcję cerkosporyny. W warunkach laboratoryjnych stwierdzono, że np. cienka warstwa pożywki PDA (Potato Dextrose Agar) w szalce Petriego sprzyja wytwarzaniu cerkosporyny podczas inkubacji grzybni na świetle. Zdolność do produkcji cerkosporyny jest cechą osobniczą, zróżnicowaną pomiędzy różnymi gatunkami rodzaju Cercospora, a nawet pomiędzy różnymi szczepami tego samego gatunku. Szczepy grzybów zdolnych do jej produkcji zawierają grupę genów CFP, które są odpowiedzialne za transport cerkosporyny przez błony komórkowe i dalej poza grzybnię do tkanek roślinnych. Brak tych genów prowadzi do niezdolności wytwarzania cerkosporyny. Cerkosporyna to czerwony barwnik, dzięki któremu w hodowlach na płytkach agarowych, można łatwo wizualnie zidentyfikować mutanty z niedoborem tej toksyny (Daub i Chung 2007). Czerwone zabarwienie obwódek plamek na liściach związane jest $\mathrm{z}$ obecnością w nich cerkosporyny. Jest ona toksyczna w stosunku do większości ro- 
ślin. W roślinach cerkosporyna działa na wiele funkcji fizjologicznych komórki, między innymi na aktywność ATP-azy oraz transport protonów (Blein i wsp. 1988). Cerkosporyna rozpuszcza błony komórkowe, co z kolei otwiera strzępkom grzyba dostęp do składników pokarmowych (Steinkamp i wsp. 1979; Daub i Ehrenshaft 2000). Dzieje się tak z powodu wytwarzania reaktywnych form tlenu przez toksynę (Daub i wsp. 2005; Choquer i wsp. 2007). Jest też toksyczna w stosunku do bakterii i niektórych grzybów (Daub i Ehrenshaft 2000). W dni pochmurne, pomimo porażenia liści, rozwój choroby jest słabszy niż w dni słoneczne (Dekkers i wsp. 2007). W badaniach nad szczepami pozbawionymi zdolności do wytwarzania cerkosporyny odkryto, że związek ten odgrywa ważną, ale niewyłączną rolę w zamieraniu liści (Esh i Moghaieb 2011). Do grupy betakolin należy dwadzieścia niebiałkowych związków oznaczonych kolejno od B0 do B19 różniących się między sobą konfiguracją izomeryczną (Milat i wsp. 1992). Są to toksyny niespecyficzne, mogące porażać wiele gatunków roślin (Goudet i wsp. 2000). Opisano szereg cytotoksycznych zjawisk powodowanych przez betakoliny w różnych roślinach. Są to między innymi spadki zawartości aminokwasów oraz $\beta$-cyjanin w korzeniach buraka (Schlösser 1969).

\section{Literatura / References}

Adams H., Schäufele W.R. 1996. Untersuchungen zum Einfluß der Cercospora-Blattfleckenkrankheit auf den Alpha-Amino-Gehalt der Zuckerrübe. s. 129-132. Proceeding of 59th International Institute for Beet Research Congress, Brussels, 15-16.02.1996, 605 ss.

Balis C., Payne M.G. 1971. Triglycerides and cercosporin from Cercospora beticola: fungal growth and cercosporin production. Phytopathology 61: 1477-1484.

Blein J., Bourdil I., Rossgnol L., Scalla R. 1988. Cercospora beticola toxin inhibits vanadate-sensitive $\mathrm{H}^{+}$transport in corn root membrane vesicles. Plant Physiology 88 (2): 429-434. DOI: 10.1104/pp.88.2.429.

Bolton M.D., Secor G.A., Rivera V., Weiland J.J., Rudolph K., Birla K., Rengifo J., Campbell L.G. 2012. Evaluation of the potential for sexual reproduction in field populations of Cercospora beticola from USA. Fungal Biology 116 (4): 511-521. DOI: 10.1016/j. funbio.2012.01.011.

Choquer M., Lee M.-H., Bau H.-J., Chung K.-R. 2007. Deletion of a MFS transporter-like gene in Cercospora nicotianae reduces cercosporin toxin accumulation and fungal virulence. The Federation of the European Biochemical Societies Letters 581 (3): $489-494$. DOI: $10.1016 /$ j.febslet.2007.01.011.

Coe G.E. 1967. Relative damage of Cercospora leaf spot in sugar beet varieties. Journal of Sugar Beet Research 15: 95-100.

Corlett M. 1991. An annotated list of the published names in Mycosphaerella and Sphaerella. Mycologia Memoir 18: 1-328.

Crane G.L., Calpouzos L. 1969. The life span and number of leaves produced by sugarbeet plants infected with Cercospora beticola. Journal of Sugar Beet Research 16: 41-44.

Crous P.W., Groenewald J.Z. 2005. Hosts, species and genotypes: opinions versus data. Australasian Plant Pathology 34 (4): $463-470$. DOI: $10.1071 / \mathrm{AP} 05082$.

Daub M.E. 1982. Peroxidation of tobacco membrane lipids by the photosensitizing toxin, cercosporin. Plant Physiology 69: 1361-1364. DOI: $10.1104 / p p \cdot 69.6 .1361$.

Daub M.E., Chung K.-R. 2007. Cercosporin: A phytoactivated toxin in plant disease. Online. The American Phytopathological Society net Features. DOI: 10.1094/APSnetFeature/2007-0207.

Daub M.E., Ehrenshaft M. 2000. The photoactivated Cercospora toxin cercosporin: contributions to plant disease and fundamental biology. Annual Review of Phytopathology 38 (1): 461-490. DOI: 10.1146/annurev.phyto.38.1.461.

Daub M.E., Herrero S., Chung K.-R. 2005. Photoactivated perylenequinone toxins in fungal pathogenesis of plants. Journal of the Federation of European Microbiological Societies Microbiology Letters 252 (2): 197-206.

Dekkers K.L., You B.-J., Gowda V.S., Liao H.-L., Lee M.-H., Bau H.-J., Ueng P.P., Chung K.-R. 2007. The Cercospora nicotianae gene encoding dual O-methyltransferase and FAD-dependent monooxygenase domains mediates cercosporin toxin biosynthesis. Fungal Genetics and Biology 44 (5): 444-454. DOI: 10.1016/j.fgb.2006.08.005.

Esh A.M.H., Moghaieb R.E.A. 2011. Analysis of morphological, pathological and genotypic diversity in Cercospora beticola Sacc. from different sugar beet cultivation in Egypt. Arab Journal of Biotechnology 14 (1): 77-88.

Goodwin S.B., Dunkle L.D. 2010. Cercosporin production in Cercospora and related anamorphs. s. 97-108. W: Cercospora Leaf Spot of Sugar Beet and Related Species (R.T. Lartey, J.J. Weiland, L. Panella, P.W. Crous, C.E. Windels, red.). American Phytopatological Society Press, 304 ss. ISBN 978-0-89054-387-0.

Goodwin S.B., Dunkle L.D., Zismann V.L. 2001. Phylogenetic analysis of Cercospora and Mycosphaerella based on the internal transcribed spacer region of ribosomal DNA. Phytopathology 91 (7): 648-658. DOI: 10.1094/PHYTO.2001.91.7.648.

Goudet C., Milat M.L., Sentenac H., Thibaud J.B. 2000. Beticolins, nonpeptidic, polycyclic molecules produced by the phytopathogenic fungus Cercospora beticola, as a new family of ion channel-forming toxins. Molecular Plant-Microbe Interactions 13 (2): $203-209$. DOI: 10.1094/MPMI.2000.13.2.203.

Groenewald M., Groenewald J.Z., Beaun U., Crous P.W. 2006. Host range of Cercospora apii and C. beticola and description of C. apiicola, a novel species from celery. Mycologia 98 (2): 275-285. DOI: 10.1080/15572536.2006.11832700.

Groenewald M., Groenewald J.Z., Crous P.W. 2005. Distinct species exist within Cercospora apii morphotype. Phytopathology 95 (8): 951-959. DOI: 10.1094/PHYTO-95-0951.

Groenewald M., Linde C.C., Groenewald J.Z., Crous P.W. 2008. Indirect evidence for sexual reproduction in Cercospora beticola populations from sugar beet. Plant Pathology 57 (1): 25-32. DOI: 10.1111/j.1365-3059.2007.01697.x.

Groenewald J.Z., Nakashima C., Nishikawa J., Shin H.D., Park J.-H., Jama A.N., Groenewald M., Braun U., Crous P.W. 2013. Species concepts in Cercospora: spotting the weeds among the roses. Studies in Mycology 75: 115-170. DOI: 10.3114/sim0012.

Hetzer E., Kiss E. 1964. Results of our research work got till now in determining the races of Cercospora beticola Sacc. Kulonlenyomat 3: $91-100$. 
Holtschulte B. 2000. Cercospora beticola - worldwide distribution and incidence. s. 5-16. W: Cercospora beticola Sacc. Biology, Agronomic Influence and Control Measures in Sugar Beet (M.J.C. Asher, B. Holtschulte, M. Richard Molard, F. Rosso, G. Steinrücken, R. Beckers, red.). Advances in Sugar Beet Reserches, International Institute for Beet Research 2, Brussels, 215 ss.

Index Fungorum. 2018. www.indexfungorum.org [dostęp: 4.08.2018].

Jacobsen B.J., Franc G.D. 2009. Cercospora leaf spot. s. 7-10. W: Compendium of Beet Diseases and Pests. Second edition. The American Phytopathological Society, St. Paul, MN, 22 ss.

Kerr E.D., Weiss A. 1990. Fungicide efficacy and yield responses to fungicide treatments based on predictions of Cercospora leaf spot of sugar beet. Journal of Sugar Beet Research 27 (3-4): 58-71.

Khan J., del Rio L.E., Nelson R., Rivera-Varas V., Secor G.A., Khan M.F.R. 2008. Survival, dispersal, and primary infection site for Cercospora beticola in sugar beet. Plant Disease 92 (5): 741-745. DOI: 10.1094/PDIS-92-5-0741.

Khan J., Qi A., Khan M.F.R. 2009. Fluctuations in number of Cercospora beticola conidia in relationship to environment and disease severity in sugar beet. Phytopathology 99 (7): 796-801. DOI: 10.1094/PHYTO-99-7-0796.

Kirk P., Cannon P., Minter D., Stalpers J. (red.). 2008. Ainsworth and Bisby's Dictionary of the Fungi. CABI, Wallingford, CT, UK, 784 ss.

Kuyama S., Tamura T. 1957. Cercosporin. A pigment of Cercospora kikuchii Matsomuto et Tomoyasu. I. Cultivation of fungus, isolation and purification of pigment. Journal of the American Chemical Society 79 (21): 5725-5726. DOI: 10.1021/ja01578a038.

Lartey R.T., Caesar-TonThat T., Caesar A.J., Sol N.I., Bergman J.W. 2005. Safflower: a new host of Cercospora beticola. Plant Disease 89 (8): 797-801. DOI: 10.1094/PD-89-0797.

Lartey R.T., Lenssen A.W., Evans R.G., Ghoshroy S. 2007. Comparative structural study of leaf spot of safflower and sugar beet by Cercospora beticola. Plant Pathology Journal 6 (1): 37-43.

Lartey R.T., Weiland J.J., Caesar-TonThat T., Bucklin-Comiskey S. 2003. A PCR protocol for rapid detection of Cercospora beticola in sugarbeet tissues. Journal of Sugar Beet Research 40 (1-2): 1-10.

Lawrence J.S., Meredith D.S. 1970. Wind dispersal of conidia of Cercospora beticola. Phytopathology 60: 1076-1078.

McKay M.B., Pool W.M. 1918. Field studies of Cercospora beticola. Phytopathology 8: 119-136.

Meredith D.S. 1967. Conidium release and dispersal in Cercospora beticola. Phytopathology 57 (8): 889-893.

Milat M.-L., Prangé T., Ducrot P.-H., Tabet J.-C., Einhorn J., Blein J.-P., Lallemand J.Y. 1992. Structures of the beticolins, the yellow toxins produced by Cercospora beticola. Journal of the American Chemical Society 114 (4): 1478-1479. DOI: 10.1021/ja00030a051.

Moretti M., Saracchi M., Farina G. 2004. Morphological, physiological and genetic diversity within a small population of Cercospora beticola Sacc. Annals of Microbiology 54 (2): 129-150.

Nagel C.A. 1938. The longevity of Cercospora beticola in soil. Phytopathology 28: 342-350.

Nowakowska H., Piszczek J., Włodarski J. 1997. Porażenie odmian buraka cukrowego przez Cercospora beticola w 1995 i 1996 roku w różnych rejonach uprawy. [Infection of sugar beet varieties by Cercospora beticola in different regions of Poland in 1995 and 1996]. Progress in Plant Protection/Postępy w Ochronie Roślin 37 (2): 340-342.

Piszczek J. 2010. Epidemiologia chwościka buraka cukrowego (Cercospora beticola) w centralnej Polsce. Rozprawy Naukowe Instytutu Ochrony Roślin 23, 62 ss.

Podlaski S. 2006. Postęp biologiczny w uprawie buraka cukrowego. Hodowla Roślin i Nasiennictwo 2: 2-6.

Pool V.W., McKay M.B. 1916a. Climatic conditions as related to Cercospora beticola. Journal of Agricultural Research 6: 21-60.

Pool V.W., McKay M.B. 1916b. Relation of stomatal movement to infection by Cercospora beticola. Journal of Agricultural Research 5 (22): 1011-1038

Rathaiah Y. 1977. Stomatal tropism of Cercospora beticola in sugarbeet. Phytopathology 67 (3): 358-362. DOI : 10.1094/Phyto-67-358.

Rees R.W., Flood J., Hassan Y., Cooper R.M. 2007. Effects of inoculum potential, shading and soil temperature on root infection of oil palm seedlings by the basal stem rot pathogen Ganoderma boninense. Plant Pathology 56 (5): 862-870. DOI: 10.1111/j.1365-3059 2007.01621.x.

Rossi V. 2000. Cercospora leaf spot infection and resistance in sugar beet. s. 17-48. W: Cercospora beticola Sacc. Biology, Agronomic Influence and Control Measures in Sugar Beet (M.J.C. Asher, B. Holtschulte, M. Richard Molard, F. Rosso, G. Steinrücken, R. Beckers, red.). Advances in Sugar Beet Reserches, International Institute for Beet Research 2, Brussels, 215 ss.

Rossi V., Meriggi P., Biancardi E., Rosso F. 2000. Effect of Cercospora leaf spot on sugar beet growth, yield and quantity. s. 49-76. W: Cercospora beticola Sacc. Biology, Agronomic Influence and Control Measures in Sugar Beet (M.J.C. Asher, B. Holtschulte, M. Richard Molard, F. Rosso, G. Steinrücken, R. Beckers, red.). Advances in Sugar Beet Reserches, International Institute for Beet Research 2, Brussels, 215 ss.

Ruppel E.G. 1972a. Variation among isolates of Cercospora beticola from sugar beet. Phytopathology 62: 134-136. DOI: 10.1094/Phyto$62-134$.

Ruppel E.G. 1972b. Negative relationship of stomal size and density with resistance in sugar beet to Cercospora beticola. Phytophatology 62: 1095-1096. DOI: 10.1094/Phyto-62-1095.

Ruppel E.G. 1986. Cercospora leaf spot. Compendium of beet diseases and insects. s. 8-9. W: Compendium of Beet Diseases and Insects (E.D. Whitney, J.E. Duffus, red.). American Phytopatogical Society Press, St. Paul, MN, 76 ss.

Saccardo P.A. 1878. Fungi Veneti novi vel critici vel mycologiae Venetae addendi. Series VI. Michelia 1 (2): $133-221$.

Saccardo P.A. 1886. Sylloge fungorum omnium hucusgue cognitorum. IV. Padova, Italy, 807 ss.

Schäufele W.R., Wevers J.D.A. 1996. Possible contribution of tolerant and partly resistant sugar beet varieties to the control of the foliar disease Cercospora beticola. Proceeding of 60th International Institute for Beet Research Congress, Cambridge, 1-3.07.1997: $19-32$.

Schlösser E. 1969. A review of some mechanisms of resistance of sugar beet to Cercospora beticola. Journal of International Institute for Beet Research 4: 185-191.

Shane W.W., Teng P.S. 1992. Impact of Cercospora leaf spot on root weight, sugar yield, and purity of Beta vulgaris. Plant Disease 76 (8): 812-820. DOI: 10.1094/PD-76-0812.

Smith G.A., Ruppel E.G. 1971. Cercospora leaf spot as a predisposing factor in storage rot of sugar beet roots. Phytopathology 61: $1485-1487$

Solel Z., Minz G. 1971. Infection process of Cercospora beticola in sugar beet in relation to susceptibility. Phytopathology 61: $463-466$.

Steinkamp M.P., Martin S.S., Hoefert L.L., Ruppel E.G. 1979. Ultrastructure of lesions produced by Cercospora beticola leaves of Beta vulgaris. Physiological Plant Pathology 15 (1): 13-26. DOI: 10.1016/0048-4059(79)90035-3. 
Tedford S.L., Burlakoti R.R., Schaafsma A.W., Trueman C.L. 2018. Relationships among airborne Cercospora beticola conidia concentration, weather variables and cercospora leaf spot severity in sugar beet (Beta vulgaris L.). Canadian Journal of Plant Pathology 40 (1): 1-10. DOI: 10.1080/07060661.2017.1410726.

Vaghefi N., Kikkert J.R., Bolton M.D., Hanson L.E., Secor G.A., Nelson S.C., Pethybridge S.J. 2017. Global genotype flow in Cercospora beticola populations confirmed through genotyping-by-sequencing. PLOS ONE 12 (10): e0186488. DOI: 10.1371/journal. pone. 0186488

Vereijssen J., Schneider J.H.M. 2003. Potential primary site of infection of Cercospora beticola in sugar beet. 1st joint International Institute for Beet Research - American Society of Sugar Beet Technologists Congress, San Antonio, 26.02-1.03.2003: 863-864.

Vereijssen J., Schneider J.H.M., Jeger M.J. 2007. Epidemiology of Cercospora leaf spot on sugar beet: modeling disease dynamics within and between individual plants. Phytopathology 97 (12): 1550-1557. DOI: 10.1094/PHYTO-97-12-1550.

Vereijssen J., Schneider J.H.M., Stein A., Jeger M.J. 2006. Spatial pattern of Cercospora leaf spot of sugar beet in fields in long- and recently-established areas. European Journal of Plant Pathology 116 (3): 187-198. DOI: 10.1007/s10658-006-9046-z.

Vereijssen J., Schneider J.H.M., Termorshuizen A.A.J. 2004. Possible root infection of Cercospora beticola in sugar beet. European Journal of Plant Pathology 110 (1): 103-106. DOI: 10.1023/B:EJPP.0000010130.38700.88.

Vereijssen J., Schneider J.H.M., Termorshuizen A.A.J. 2005. Root infection of sugar beet by Cercospora beticola in a climate chamber and in the field. European Journal of Plant Pathology 112 (3): 201-210. DOI: 10.1007/s10658-004-4172-y.

von Thümen F. 1886. Die Bekämpfung der Pilzkrankheiten unserer Culturgewächse: Versuch einer Pflanzentherapie zum praktischen Gebrauche für Land- und Forstwirthe, Gärtner, Obst- und Weinzüchter. Journal of Mycology 5 (2): 107-111.

Wallin J.R., Loonan D.V. 1972. The increase of Cercospora leaf spot in sugar beets and periodicity of spore release. Phytopathology 62: $570-572$

Weiland J., Koch G. 2004. Sugarbeet leaf spot disease (Cercospora beticola Sacc.) dagger. Molecular Plant Pathology 5 (3): $157-166$. DOI: $10.1111 /$ j.1364-3703.2004.00218.x.

Windels C.E., Lamey H.A., Hilde D., Widner J., Knudsen T. 1998. A Cercospora leaf spot model for sugar beet: In practice by an industry. Plant Disease 82 (7): 716-726.

Wolf P.F.J., Heindl M., Verreet J.A. 2001. Influence of sugar beet leaf mass development on predisposition of the crop to Cercospora beticola (Sacc.). Zeitschrift für Pflanzenkrankheiten und Pflanzenschutz / Journal of Plant Diseases and Protection 108 (6): $578-592$. 